\title{
Gut Virome as a New Target for Diet Intervention in Promoting Health
}

\author{
Torrinhas RS* and Waitzberg DL \\ Department of Gastroenterology, University of São Paulo, Brazil
}

Submission: April 23, 2017; Published: May 30, 2017

*Corresponding author: Torrinhas RS, Av. Dr. Arnaldo, 455, $2^{\circ}$ andar, sala 2208-Cerqueira César, CEP: 01246-903, São Paulo-SP, Brazil, Tel: +55-11-3061-7459; Email: rtorrinhas@gmail.com

\begin{abstract}
The co-evolution of our ancestors with viruses was recorded in our genome, which has about $8 \%$ of its material from endogenous viral fragments. Some of human viral-encoding proteins may sustain important physiological functions, such as mammal placental morphogenesis. It is then reasonable to consider that the human virome may continuously impact on our body homeostasis. We here briefly discusses evidences that human virome may be modulated by diet and how this may impact on human health.
\end{abstract}

Keywords: Microbiota; Virome; Diet; Health

\section{Introduction}

Human microbiota has been considered as a "newly discovered organ" since its potential impact on human body homeostasis was recognized [1]. Microbiota organisms may promote human health or contribute to human diseases, depending on the nature of its relationship with our body and other multi factorial conditions which remain largely unknown [2]. Some auto-immune, allergic, inflammatory, cardiac and neurologic diseases, obesity, and perhaps some cancers seem to develop under the active participation of our resident microbiota.

A major link between microbiota and human diseases has been established from studies enrolling its bacterial component, mainly those inhabiting gut. These studies were able to show, for instance, that obese subjects can exhibit a ratio of Firmicutes and Bacteroidetes phyla tenfold higher than lean subjects [3]. In addition, this structural characteristic of gut resident bacteria from obese subjects is associated with a shift in its function, resulting in increased energy harvest from ingested food with consequent deposition of unexpended excess energy as adipose tissue [4].

Although viruses represent the most abundant components of the human microbiota family, the number of studies evaluating its impact on human health is low when comparing with those assessing the bacterial component. This scenario is a consequence of a higher difficulty to identify viruses in human microbiota samples rather than the resident bacteria.
Different from bacteria, which contain a particular version of the $16 \mathrm{~S}$ ribosomal RNA gene to enable its identification, the viruses have no analogous identification marker. However, advances in next-generation sequencing and in sequence assembly techniques are enabling to better access the genome content and architecture of uncultured viruses [5]. These data are providing evidences that, once seen as merely invasive pathogens, viruses can, indeed, take part of human biology.

A viral fraction of human microbiota is dominated by bacteriophages, meaning that they inhabit bacteria instead human cells. Nevertheless, bacteriophages may indirectly impact on human health by influencing bacterial functions and abundance. For instance, bacteriophage may play a crucial role in bacterial virulence against human hosts. Phage may integrate genes into the bacteria genetic machinery that provides abilities for antibiotics resistance or to produce harmful toxins [6-8]. These new bacteria's abilities can be transferred to their future generations. Moreover, the interaction between the bacterial and viral genetic materials may produce a new generation of viruses. In mice, intestinal Enterococcus faecalis unleashed a new bacteriophage composed from two different phages. This new phage provided to $E$. faecalis strains a competitive advantage over other bacteria to colonize the intestines [9].

The interference of phage on the microbiota's bacteria function and composition to drive the human body for health 
or disease is just beginning to be studied. A study of Barr et al. [10] suggests that phages may represent an additional mucosal barrier for potential pathogens. These authors assessed the effect of Escherichia coli exposure on human mucus-producing cells that had been pre-treated with phage T4, after observing that the lytic T4 phage adherence to human cell lines was dependent of mucus production. Both bacterial adherence and epithelial cell death were lower for T4-treated cells than for non-treated cells, suggesting that the phage form an antimicrobial layer that decreases mucus colonization by bacteria and thus protects the underlying epithelial cells from infection [10].

Although modest, these new observations break the old paradigm that viruses are associated only to diseases. Notably, even the eukaryotic virome may contribute to human health by impacting innate and adaptive immunity [11]. A range of pathological virus has been shown to compose the virome of asymptomatic subjects, suggesting an adaptation of our immune responses to avoid immune pathologic damage of persistently infected tissues [12]. The immunologic imprint generated by these responses may improve our capacity to fight against subsequent infections and influence the nature of tissue immunity and inflammation [12]. In health conditions, human viroma displays a high level of inter-individual variation, but $80 \%$ virotype within an individual can persist over 2.5 years [13-15]. However, greater similarity between viromescan be found between individuals eating the same diet [14], suggesting that human virome may be modulated by the type of food ingested. Furthermore, small plant-derived viruses are being identified and show to affect the intestinal bacterial composition and function with consequences for the human host [16]. These findings open a new area for nutritional intervention, and perhaps use of probiotics and prebiotics to promote health [17].

\section{References}

1. Kelly D, Mulder IE (2012) Microbiome and immunological interactions. Nutr Rev 70(1): 18-30.

2. Cho I, Blaser MJ (2012) The Human Microbiome: at the interface of health and disease. Nat Rev Genet 13(13): 260-270.

3. Ley RE, Turnbaugh PJ, Klein S, Gordon JI (2006) Microbial ecology: human gut microbes associated with obesity. Nature 444(7122): 1022-1023.
4. Turnbaugh PJ, Ley RE, Mahowald MA, Magrini V, Mardis ER, et al. (2006) An obesity-associated gut microbiome with increased capacity for energy harvest. Nature 444: 1027-1031.

5. Kristensen DM, Mushegian AR, Dolja VV, Koonin EV (2010) New dimensions of the virus world discovered through metagenomics. Trends in microbiology 18(1): 11-19.

6. Waldor MK, Mekalanos JJ (1996) Lysogenic conversion by a filamentous phage encoding cholera toxin. Science 272(5270): 19101914.

7. Brüssow H, Canchaya C, Hardt WD (2004) Phages and the evolution of bacterial pathogens: from genomic rearrangements to lysogenic conversion. Microbiol Mol Biol Rev 68(3): 560-602.

8. Sekulovic O, Meessen Pinard M, Fortier L (2011) Prophage-Stimulated Toxin Production in Clostridium difficile NAP1/027 Lysogens. J Bacteriol 193(11): 2726-2734.

9. Duerkop BA, Clements CV, Rollins D, Rodrigues JLM, Hooper LV (2012) A composite bacteriophage alters colonization by an intestinal commensal bacterium. Proc Natl Acad Sci USA 109(43): 1762117626.

10. Barr JJ, Auro R, Furlan M, Whiteson KL, Erb ML, et al. (2013) Bacteriophage adhering to mucus provide a non-host-derived immunity. Proc Natl Acad Sci USA 110(26): 10771-10776.

11. Wylie KM, Mihindukulasuriya KA, Zhou Y, Sodergren E, Storch GA, et al. (2014) Metagenomic analysis of double-stranded DNA viruses in healthy adults. BMC Biol 12: 71.

12. Virgin HW, Wherry EJ, Ahmed R (2009) Redefining chronic viral infection. Cell 138(1): 30-50.

13. Reyes A, Haynes M, Hanson N, Angly FE, Heath AC (2010) Viruses in the faecal microbiota of monozygotic twins and their mothers. Nature 466(7304): 334-338.

14. Minot S, Sinha R, Chen J, Li H, Keilbaugh SA, et al. (2011) The human gut virome, inter-individual variation and dynamic response to diet. Genome Res 21(10): 1616-1625.

15. Minot S, Bryson A, Chehoud C, Wu GD, Lewis JD, et al. (2013) Rapid evolution of the human gut virome. Proc Natl Acad Sci USA 110(30): 12450-12455.

16. Zhang, Breitbart M, Lee WH, Run JQ Wei CL, et al. (2006) RNA viral community in human feces: prevalence of plant pathogenic viruses. PLoS Biol 4: 3 .

17. Scarpellini E, Ianiro G, Attili F, Bassanelli C, De Santis A, et al. (2015) The human gut microbiota and virome: Potential therapeutic implications. Dig Liver Dis 47(12): 1007-1012.
This work is licensed under Creative

Commons Attribution 4.0 License

DOI: 10.19080/NFSIJ.2017.02.555598
Your next submission with Juniper Publishers will reach you the below assets

- Quality Editorial service

- Swift Peer Review

- Reprints availability

- E-prints Service

- Manuscript Podcast for convenient understanding

- Global attainment for your research

- Manuscript accessibility in different formats

( Pdf, E-pub, Full Text, Audio)

- Unceasing customer service

Track the below URL for one-step submission https://juniperpublishers.com/online-submission.php 